\title{
Myelodysplastic syndrome in a patient with HCV cirrhosis. Case report
}

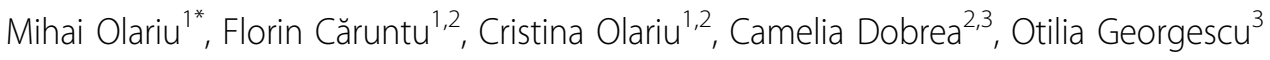 \\ From The 9th Edition of the Scientific Days of the National Institute for Infectious Diseases Prof Dr Matei \\ Bals \\ Bucharest, Romania. 23-25 October 2013
}

\section{Background}

Myelodysplastic syndromes are clonal myeloid disorders marked by ineffective hematopoiesis, cytopenia and qualitative disorders of blood cells that have a variable predilection to undergo clonal evolution to acute myelogenous leukemia. Chronic infection with hepatitis $\mathrm{C}$ virus (HCV) induces a chronic stimulation of B lymphocytes and, in some cases, this stimulation can lead to chronic lymphoid disorders like non-Hodgkin lymphoma.

\section{Case report}

We report a case of myelodysplastic syndrome (overt multilineage dysmorphic cytopenia) in a 54 year-old man who had HCV cirrhosis with HCV. The patient was diagnosed with cirrhosis in December 2011 in our Institute. From 2011 to April 2013 the blood counts were relatively normal with mild to moderate thrombocytopenia. On April 2013 the patient presented with pallor, asthenia, weakness and dyspnea. Blood count showed pancytopenia with severe anemia: hemoglobin $6.2 \mathrm{~g} / \mathrm{dL}$. We performed a bone marrow biopsy that indicated the morphological changes on erythropoiesis, granulopoiesis and thrombopoiesis. The patient received red cells transfusion and he was transferred to the Fundeni Clinical Institute where cytogenetic abnormalities showed loss of Y chromosome in 4 metaphases. The patient received recombinant human erythropoietin every month and the blood count in June 2013 was as follows white blood cells $3.4 \times 10^{9} / \mathrm{L}$, hemoglobin $13 \mathrm{~g} / \mathrm{dL}$, platelets $85 \times 10^{9} / \mathrm{L}$.

\section{Conclusion}

In the past few years we have observed a number of cases with $\mathrm{HCV}$ infection that associated myelodysplastic

\footnotetext{
* Correspondence: ol_mihai@yahoo.com

${ }^{1}$ National Institute for Infectious Diseases "Prof. Dr. Matei Balş", Bucharest, Romania

Full list of author information is available at the end of the article
}

syndromes and our question is if HCV may be implicated in the etiology of these syndromes, but further studies are necessary to verify this hypothesis.

\section{Authors' details}

'National Institute for Infectious Diseases "Prof. Dr. Matei Balş", Bucharest, Romania. ${ }^{2}$ Carol Davila University of Medicine and Pharmacy, Bucharest, Romania. ${ }^{3}$ Fundeni Clinical Institute, Bucharest, Romania.

Published: 16 December 2013

\section{doi:10.1186/1471-2334-13-S1-P94}

Cite this article as: Olariu et al:: Myelodysplastic syndrome in a patient with HCV cirrhosis. Case report. BMC Infectious Diseases 2013 13(Suppl 1): P94.
Submit your next manuscript to BioMed Central and take full advantage of:

- Convenient online submission

- Thorough peer review

- No space constraints or color figure charges

- Immediate publication on acceptance

- Inclusion in PubMed, CAS, Scopus and Google Scholar

- Research which is freely available for redistribution
() Biomed Central
C Biomed Central

(C) 2013 Olariu et al; licensee BioMed Central Ltd. This is an Open Access article distributed under the terms of the Creative Commons Attribution License (http://creativecommons.org/licenses/by/2.0), which permits unrestricted use, distribution, and reproduction in any medium, provided the original work is properly cited. 